УДК 792.796(045)

DOI: https://doi.org/10.51209/platform.1.3.2021.68-84

Денис Ігорович ШАРИКОВ,

кандидат мистецтвознавства,

Київська муніципальна академія естрадного

та циркового мистецтв,

Київ, Україна, e-mail: d.ballet77@gmail.com,

ORCID:nb 0000-0002-3757-5559

\title{
ЖОНГЛЮВАННЯ В СУЧАСНОМУ ЦИРКОВОМУ МИСТЕЦТВІ: ЗНАЧЕННЯ, ОСОБЛИВОСТІ
}

\begin{abstract}
Анотація. У статті охарактеризовано специфіку викладання жонглювання як циркового жанру в умовах сьогодення. Визначається особливості формально-технічних засобів циркового жанру жонглювання, описані методи його втілення у сценічній репрезентації на цирковому манежі сьогодення. Надається короткий аналіз досліджень із даної проблематики в контексті історії та виконавства. Описується специфіка методичних особливостей жонглювання, яке сприяє розвитку координації, периферійного зору i контролю предметів, циркову техніку, яку використовують як елемент виховання акторської пластики та сценічного руху. Сучасна циркова культура у галузі жонглювання, спираючись на конкретні класичні методи та систему, збагачується наслідками взаємодії мистецтва 3 новітніми технологіями, матеріалами, формами. Це надає можливості молодим артистам цирку у галузі жонглювання здобути конкурентоспроможність на сучасних світових фестивалях і конкурсах.
\end{abstract}

Ключові слова: циркове мистецтво, жонглювання, специфіка викладання, реквізит, тренування 
Вступ. У статті описані найвідоміші підходи до вивчення циркового жанру жонглювання та наведені практичні поради до нього, що є базою для вивчення жанру у закладі вищої освіти.

Постановка проблеми зумовлена тим, що нині жонглювання є популярним і запитуваним жанром у сучасних циркових постановках та виставах. Але часто артисти у гонитві за оригінальністю нехтують базовими азами техніки, яка $€$ основою саме класичного жонглювання. Підгрунтям аматорського циркового мистецтва $\epsilon$ інтерес та внутрішня мотивація артиста. Професійне жонглювання потребує вивчення та дослідження досягнень відомих майстрів своєї справи, їхніх технік, методики. 3 досвіду практичного втілення тих чи інших технік на сцені формується основа для передачі знань майбутнім поколінням артистів.

Аналіз останніх досліджень і публікацій. Циркознавчі дослідження у галузі жонглювання сьогодні передусім присвячені історичному процесу розвитку жанру, творчого шляху його відомих представників, а також подекуди - техніки сучасного жонглювання. Серед зарубіжних авторів найгрунтовніших праць про цирк: В. Барінов [1], Е. Бауман, Ю. Дмитрієв [6], Г. Гуревич [5], Д. Жандо, А. Кісс [7], Є. Кузнєцов, Р. Славський [20], вітчизняне циркознавство поки рясніє лише поодинокими штудіями в галузі як окремих жанрів циркового мистецтва, так і у полі теорії та історії цирку загалом [11-18; 19; 23].

Мета дослідження полягає у визначенні специфічних особливостей викладання жанру класичного жонглювання у сучасних ЗВО для постановки циркового номеру.

Виклад основного матеріалу. Жанр жонглювання цікавий і нестандартний, особливо у синтезі з іншими жанрами. Його майстри мають деяку перевагу: реквізит жонглера завжди 3 собою, а показ майстерності може відбуватися практично на будь-якому майданчику. Тому прояви цього жанру не обмежуються лише контекстом циркової діяльності, зокрема, 
манежем.

Жонглювання, як і більшість інших циркових жанрів, мистецтво історично сімейне, часто артисти працюють у галузі цілими династіями. Інформація про досягнення, особливості техніки, методи передається 3 вуст в уста. Більшість тих науково-методичних розробок, які присвячені жанру, - здобуток радянського часу. Хоча, варто зазначити, що в них подані дуже важливі основи жонглювання.

Окремі аспекти розвитку українського цирку, зокрема, $\mathrm{i}$ жонглювання у 20-х рр. ХХ ст., представлено в монографіях та статтях мистецтвознавців, істориків, а також у листах, переписках артистів цирку. Так, Є. Кузнєцовим у праці «Арена и люди советского цирка» проаналізовано внесок українських циркових артистів у розвиток вітчизняного та світового цирку [13].

Праця Ю. Дмитрієва «Советский цирк...» містить у собі аналіз основних тенденцій розвитку циркового мистецтва у першій половині XX століття в радянських республіках, в тому числі Україні. Джерелом відомостей про український цирк $є$ монографії, присвячені найяскравішим його представникам. Можна зазначити монографії Р. Славського «Виталий Лазаренко» (1980 р.) та «Братья Никитины» (1987 р.), О. Таланова «Братья Дуровы» (1971 р.) [13].

Чільне місце серед радянських праць, присвячених саме жонглюванню, посідає робота М.Е. Баумана «Искусство жонглирования», яка була надрукована 1962 р. У книзі доступно викладений саме методичний матеріал, яким Бауман згодом охоче ділився у своїх інтерв'ю тогочасним періодичним виданням [3]. М. Бауман, у минулому - жонглер, мав багаторічний педагогічний досвід, і у нього з'явилася певна школа викладання. Автор розповідає про жонглювання «класичними» предметами (м'ячами, булавами, кільцями), предметами різної форми і ваги, про балансування, сольну роботу i групову ексцентрику, методику тренування, про виготовлення реквізиту, про костюм жонглера, режисуру. 
Бауман наводить приблизні сценарії номерів, детально описує техніку виконання трюків, подаючи матеріал за складністю. Такий виклад допомагає любителям і професійним артистам правильно будувати свої тренування і виконувати той чи інший трюк.

M. Бауман зібрав і систематизував великий корпус матеріалу. Його режисерський і педагогічний діапазон дуже широкий - від жонглювання до акробатики і повітряної гімнастики. За двадцять років роботи в цирковому училищі він підготував велику кількість номерів у різних жанрах.

На жаль, критики зазначають, що автор не дослідив перспективи творчого розвитку жанру. В тогочасних циркових та естрадних номерах $є$ цікаві трюки, які осучаснили цей давній вид мистецтва. «Бауману варто було б підказати артистамаматорам що-небудь нове, оригінальне, оскільки його посібник задумано набагато ширше, ніж тільки методика основ жонглювання. Варто було б познайомити читачів і 3 досвідом таких майстрів, як Енріко Растеллі, Віолетта та Олександр Кісс, розповісти про жонглювання, що поєднується 3 елементами інших жанрів», - зазначає рецензент А. Ширай після виходу книги дослідника [20, с. 34]. Також у книзі немає візуального супроводу, тому доводиться лише уявляти виступи артистів.

Загалом, за останні 20 років зусиллями математиків відбулося безліч важливих відкриттів у галузі жонглювання. Найважливішим серед них, очевидно, було створення нотацій сайтсвопу. I цікаво, що їх починали розробляти різні люди незалежно один від одного приблизно в один і той самий час.

Основна ідея сайтсвопу полягає у розбитті процесу жонглювання на «стани», моменти часу, що описуються рядком цифр. Цифри говорять про розташування м'ячів у цей момент, але йдеться не про їхне точне положення в просторі. Поняття «стану» не несе конкретного сенсу. Ця абстрактна категорія необхідна для подальших побудов комбінацій. Знаючи, яким чином м'ячі змінюють один одний, можна будувати діаграму, за якою легко вигадувати трюки, а також пов'язувати між собою вже відомі. 
Такі наукові математичні розрахунки дозволили у майбутньому на основі спостережень узагальнити та точніше описати рухи жонглерів. Вони виконуються за спеціальними надточними схемами - патернами, у яких кожна рука, в ідеалі, робить точні й однакові рухи.

Спеціально для Санкт-Петербурзького міжнародного культурного форуму, секції «Циркового і вуличного мистецтва» було надруковане тематичне видання «Жонглеры в лицах» під керівництвом засновника і міжнародної циркової енциклопедії «Circopedia» Д. Жандо. Видання містить коротку історію жонглювання, подану через призму особистостей артистів та їхніх досягнень у певні епохи. Укладачі описують розвиток циркового жанру, акцентуючи увагу на радянському i пострадянському просторі, але подають у загальному контексті хронології й історію та досягнення закордонних майстрів циркового мистецтва.

Видання розповідає про деякі інновації в жонглюванні й техніки основних напрямків та різновидів, які $є$ популярними й нині: жонглювання побутовими предметами, жонглювання кільцями, контактне жонглювання та синтез жонглювання 3 танцем або з елементами акробатики. Охоплено періоди від двох тисяч років до нашої ери до сьогодення. У книзі подані описи та короткі біографічні дані представників жанру жонглювання, виокремлені найвизначніші й найважливіші постаті: ті, хто зробив найзначніший внесок $у$ розвиток та збагачення жонглювання як окремого жанру циркового мистецтва [22].

Особливістю цього видання $є$ візуальна складова фотографії артистів під час репетицій та виступів. Завдяки цьому можна не лише уявляти, що хотіли передати автори, а й побачити, як це було насправді. Ілюстрації супроводжують текстовий блок про кожного артиста-жонглера або групу чи колектив, які ввійшли в опис. Вони чорно-білі, але це не заважає зрозуміти, який сценічний образ мав артист, чи яким було його творче спрямування загалом.

Ще однією цікавою роботою 3 жонглювання є книга під назвою «Научитесь учиться или жонглировать», яка була 
створена на основі психологічної методики «картки пам'яті». Цю методику розробляв психолог та редактор міжнародного журналу «Менс» Тоні Б'юзен у співавторстві 3 жонглером та винахідником методики «метафоричного жонглювання» [4]. Одною $з$ головних й вирішальних ідей книги є те, що не треба думати, як зловити м'яч у процесі жонглювання, головне думати над тим, як його кинути, щоб не довелось перейматись першим. Загалом ця книга розповідає, як навчитися досягати успіху через теорію «метафоричного жонглювання», але фактично це посібник із класичного жонглювання. На прикладі цього виду мистецтва автори пояснюють цікаві приклади зі свого життя, що давали їм можливості знаходити техніки, які допомагають у розвитку та підвищують ефективність навчання.

Автори запевняють: якщо використовувати всі поради книги, то можна стати одним 3 найкращих жонглерів. Тоні Б’юзен та Майкл Гелб акцентують увагу на тому, що набагато ефективніше вчитись жонглювати й читати книгу в процесі, а також ніколи не робити цього наодинці. Їхня перша важлива порада - знайти колегу або друга, з яким можна тренуватися разом. У роботі описані методики впевненості в собі, концентрації уваги та адекватного зусилля, що допомагають витрачати на розвиток тільки ті сили, які для цього необхідні. I все це паралельно 3 опануванням основ класичного жонглювання.

Специфіка жонглювання та репрезентативна характеристика свідчить про те, що кінцевим локальним результатом для артиста жонглера $є$ створення номеру. Цирковий номер - художній витвір циркового мистецтва. Це сукупність у відповідній структурній послідовності елементів, які у поєднанні 3 іншими сценічними засобами виразності відображають творче завдання, ідею та впливають на глядачів на емоційному рівні. Сучасний рівень розвитку циркового мистецтва потребує всебічної підготовки артиста.

Розробка та постановка циркового номера - це тривалий процес пошуку, компіляції, створення та вдосконалення. Його можна розділити на кілька основних етапів. Цей поділ не можна 
вважати виключно правильним, адже багато факторів впливають на майбутній номер: стать/вік виконавця, обраний реквізит, соло чи груповий, сюжетний чи безсюжетний тощо. Було виокремлено такі етапи створення циркового номеру:

- технічна підготовка виконавця: відпрацювання елементів обраного жанру, напрацювання трюкової бази, складання трюкових зв'язок, виявлення рівня складності (унікальності);

- виконання окремого/окремих елементу/елементів для виразності постановочного номеру;

- підготовчий: створення або підбір музичного матеріалу;

- вивчення та опрацювання елементів хореографії та пластики як додаткового засобу для підсилення характеру образу;

- розробка костюму, гриму та їх тестування;

- $\quad$ передфінальний: відпрацьовування номеру під музичний супровід, у відповідному костюмі, гримі, 3 реквізитом (якщо реквізит у поставленому номері повинен лише підкреслити образ виконавця, де він перетворюється на декорацію), у певному приміщенні;

- фінальний: показ поставленого номеру «на глядача»;

- постфінальний: «робота над помилками», критика, опрацювання оцінок, зауважень.

У перші роки навчання майбутній артист, фактично, займається лише першим етапом із цього списку, тобто, напрацьовує техніку кидка i трюкову базу. Окрім цього, важливою є загальна фізична підготовка та усвідомлення, що не всі фізичні вправи можна поєднувати 3 жонглюванням, або виконувати перед жонглюванням.

Наприклад, у жодному випадку педагоги не рекомендують займатись на перекладині перед жонглюванням. Це перевантажує м'язи, що негативно впливає на точність кидку. М'язи затискаються перед тренуванням і не дають можливості продуктивно та безпечно працювати, а це сприяє неправильному розвитку м'язів та координації загалом. Краще займатись на перекладині після жонглювання. Тоді при належних вправах 
вона розтисне м'язи і зможе зняти навантаження зі спини та плечового поясу.

Необхідно виконувати розминку, в якості якої можуть бути розтягування спини та плечей, відтискання від підлоги до 10 разів (до першого болю у м'язах). Також слід робити рухи по колу в тілі згори вниз (шия, плечі, тулуб, лікті, кисті, стегна, коліна, стопи). Це необхідно для розігріву м'язів, суглобів та запобігання подальшого травмування.

Існує спосіб швидкої розминки для жонглювання. Він полягає у тому, щоб тримати руку зігнуту в лікті долонею вниз 3 м'ячиком у руці і швидко відпускати та ловити його, не перевертаючи руку. Ця вправа потрібна для швидкого ввімкнення в тонус групи м'язів, що відповідають за жонглювання. Ефективнішою ця вправа буде, якщо розминати дві руки одночасно. Велику увагу треба приділяти розминці та закачуванню м'язів спини, тому що вони відчувають найбільше напруження під час класичного жонглювання.

Науково підтвердженим $є$ факт позитивного впливу жонглювання на людський мозок. За рахунок активізації та взаємодії обох півкуль головного мозку одночасно нейронна мережа головного мозку починає розвиватися. У свою чергу, іï розвиток активізує зону мозку, що відповідає за пам'ять. Усе це допомагає запам'ятовуванню великої кількості необхідної інформації, швидшому читанню і вивченню іноземних мов.

Методичні особливості жонглювання свідчать про те, що цей жанр сприяє розвитку координації, периферійного зору i контролю предметів. А тому його як циркову техніку використовують як елемент виховання акторської пластики та сценічного руху. Але щоб стати жонглером-професіоналом, не достатньо лише базових умінь. Потрібна методика i послідовність викладу матеріалу. Складність дослідження полягає у тому, що багато артистів - практики i, маючи певні напрацювання, не фіксують їх у письмовому вигляді. Через це виникає дефіцит інформації.

Жонглер і режисер Микола Бауман радить проводити навчальний урок із жонглювання тривалістю 45 хвилин. Для 
початку потрібно знайти два м'ячики, що будуть відрізнятися за кольором. Це необхідно для того, щоб легше сприймати предмет у повітрі. Перед тим, як жонглювати, потрібно стати в правильну позицію, «позицію жонглера»: спина рівна, плечі розвернуті, ліва нога для втримання на підлозі висувається трохи вперед із напівзігнутим коліном, рівна права нога лишається позаду. Руки зігнуті в ліктях, але не напружені, щоб зайва напруга не заважала точності кидка, лікоть на ширині плечей, долоні дивляться вгору, а пальці - напівзігнуті.

На першому тренуванні необхідно взяти один м'яч будьякого кольору та перекидати його на рівні очей протягом 20 хвилин, при цьому потрібно не розводити лікті, а за м'ячем підходити зберігаючи стійку. Після 20 хвилин вправ із одним м'ячиком можна брати 2 м'ячі іншого кольору, один в праву руку, один в ліву руку. Кинути м'яч потрібно з ведучої руки на рівні очей, а потім, коли перший м'яч почне падати, потрібно назустріч йому кинути другий м'яч. Таку вправу необхідно виконувати 20 хв протягом 3-4 днів. Коли учень навчиться виконувати цю вправу, необхідно взяти третій м'яч. Третій м'яч треба тримати ведучою рукою. Наприклад, у лівій руці один м'яч, затиснути 5 пальцями, у правій руці - два м'ячики: перший м'яч затиснути трьома пальцями (вказівний, великий та середній), а другий м'яч затиснути мізинцем, безіменним пальцем та долонею. Поштовхом трьох пальців потрібно викинути перший м'яч із правої руки в повітря, поштовхом усієї долоні треба викинути другий м'яч із лівої руки назустріч першому, і третій м'яч - назустріч другому. Робити кидок необхідно круговим рухом від грудей у бік протилежного плеча.

Намічений м'ячиками малюнок має нагадувати дві дуги, спрямовані в протилежні боки. Цю вправу необхідно виконувати протягом 2-3 тижнів, але враховувати план наступних тренувань: перші 20 хвилин - це робота 3 одним і двома м'ячиками, інший час - робота 3 трьома м'ячиками та засвоєння нового. Увесь час потрібно слідкувати за рівною поставою, вона має увійти в звичку. 
Коли учень вміє жонглювати трьома м'ячиками, можна додати до них четвертий м'яч. Для цього необхідно взяти в кожну руку по два м'ячики. Але тут техніка кидка інша. Для початку потрібно кинути м'яч правою рукою «не в темп», після цього кинути м'яч лівою рукою. Особливість жонглювання четвіркою полягає у тому, що м'яч повертається в ту руку, яка його викинула. Кидок виконується напівколовим рухом на те саме плече, з якого кидає рука. Малюнок нагадує дві дуги згори і два кола на повний зріст. Кожна рука жонглює по два м'ячики окремо, дуги відрізняються від жонглювання трьома м'ячиками тому що вони не перетинаються. Цю вправу необхідно виконувати 4-8 уроків по 45 хвилин, один урок на день.

Висновки. Жонглювання - це давній жанр циркового мистецтва. Його історія починається до нашої ери й триває до нашого часу. Техніка жонглювання постійно вдосконалюється й розвивається в усіх можливих напрямках. Цьому сприяють як аматори, так i професіонали цього жанру. Кожен виконавець вносить щось нове до цього жанру.

До основних завдань теоретичних розробок у галузі жонглювання сьогодні належать:

- стан дослідження класичного циркового жонглювання у науковій та науково-популярній літературі;

- аналіз історичного процесу розвитку циркового жонглювання, починаючи 3 перших згадок про цей жанр з часів Стародавнього Єгипту;

- $\quad$ аналіз специфічних рис жанру циркового жонглювання. Особливості класичного жонглювання - у можливості жонглювати великою кількістю предметів (нині зафіксований рекорд становить 14 предметів), у той час як без використання спеціального реквізиту та у поєднанні 3 іншими жанрами циркового мистецтва ця кількість зменшується до 3-5 предметів; - систематизація знань про методику та особливості викладання класичного жонглювання, що базується на працях М. Баумана, Ш. Елерса та М. Дж. Гелба у співавторстві 3 Т. Б'юзеном. Їх переваги - у можливості опанувати базову техніку класичного кидку з трьома предметами у доволі стислі 
терміни. Але жодну техніку не можна використовувати як єдину на шляху до професійного опанування жанру класичного жонглювання.

Хоча жонглювання й потребує багаточасової праці та роботи над собою щодня, це не зупиняє послідовників цього виду мистецтва та спорту в усього світі. Інновації та поєднання жонглювання 3 іншими жанрами дали нові можливості для розвитку цього виду творчої діяльності, нових методів виразності, нового бачення вже відомого циркового напряму. Підтвердження цього - винесення жонглювання за межі цирку і циркового манежу на вулицю, на естраду, на театральну сцену та синтез його з іншими жанрами.

Сьогодні майже жодне циркове шоу або вистава не обходиться без виступів жонглерів, а тому за досить тривалий час жонглювання зазнало істотних змін, перетворень і поєднань. Та саме класичне жонглювання залишається основою для опанування цього жанру загалом.

\section{Література}

1. Бардиан Ф. Советский цирк на пяти континентах. Москва: Наука, 2015. 206 с.

2. Баринов В. Эстетика циркового наива. Москва: Мир, 2016. 308 с

3. Бауман Н. Искусство жонглирования. Москва: Искусство, 1962. 126 с.

4. Гелб М.Дж., Бьюзен Т. Научитесь учиться или жонглировать. Минск: ООО «Попурри», 2000. 176 с.

5. Гуревич 3. О жанрах советского цирка: учебное пособие для училищ циркового и эстрадного искусства и отделений режиссуры цирка театр, институтов. Москва: Искусство, 1984. $303 \mathrm{c}$.

6. Дмитриев Ю. Советский цирк. Очерки истории 1917 1941. Москва: Искусство, 1963. 400 с.

7. Кисс А. Если ты - жонглёр... Москва: Искусство, 1971. $124 \mathrm{c}$. 
8. Клудский К., Цибула В. Жизнь на манеже. Москва: Искусство, 1981. 232 с.

9. Кузнецов Е. Цирк: происхождение, развитие, перспективы. Москва: Искусство, 1971. 448 с.

10. Макаров С. Театрализация цирка. Москва: Либроком, 2015. 287 с.

11. Малихіна М. Проблема використання синтезу мистецтв у професійній підготовці артистів цирку. Культура і сучасність. 2009. № 1. Сc. 151-161.

12. Малихіна М. Проблема створення манежного образу. Культурно-мистецькі обрії. Частина І. Київ, 2016. Сс. 57-59.

13. Малихіна М. Модифікація циркового мистецтва в Україні: 20-і роки XX століття. Вісник Національної академії керівних кадрів культури і мистецтв. Київ, 2013. № 2. Сc. $160-164$.

14. Пожарська О. Зміст та функції циркового видовища. URL: $\quad$ https://knowledge.allbest.ru/culture/3c0a65625a3a c68a5c43a99521316d27 0.html

15. Романенкова Ю. Современное цирковое искусство как поле для борьбы со стереотипами. Арт-платформа. 2020. Вип. 1. Cc. 69-93.

16. Романенкова Ю. Сучасна українська циркова школа як інструмент презентування країни у світовому культурному просторі. Молодий вчений. 2020. Вип. 3(79). Сс. 69-73.

17. Романенкова Ю. К вопросу о месте цирковедения в современной украинской гуманитаристике. Сучасні тенденції розвитку науки. Ужгород, Херсон, 2018. Сс. 150-153.

18. Романенкова Ю. Цирковое искусство как культурный маркер современной Украины. Science, research, development. Warszawa, 2018. Pp. 150-153.

19. Румянцев, М. Н. На арене советского цирка. Москва: Искусство, 2015. 136 с.

20. Ширай А. Книга Н. Э. Баумана «Искусство жонглирования». Советский цирк. 1963. № 7. С. 34.

21. Шнеер А., Славский Р. Цирк. Маленькая энциклопедия. Москва: Советская Энциклопедия, 2016. 376 с. 
22. Circopedia. URL: http://www.circopedia.org/Main_Page

23. Romanenkova J., Paliychuk A., Sharykov D., Bratus I., Kuzmenko H., Gunka A. Circus art in modern realities: functions, problems, prospects. Revista inclusiones. 2021. Vol. 8. 571-581.

\title{
Денис Игоревич ШАРИКОВ,
}

кандидат искусствоведения,

Киевская муниципальная академия

эстрадного и циркового искусств,

Киев, Украина,

e-mail: d.ballet77@gmail.com,

ORCID: 0000-0002-3757-5559

\section{ЖОНГЛИРОВАНИЕ В СОВРЕМЕННОМ ЦИРКОВОМ ИСКУССТВЕ: ЗНАЧЕНИЕ, ОСОБЕННОСТИ}

\begin{abstract}
Аннотация. В статье охарактеризована специфика преподавания жонглирования как циркового жанра в сегодняшних условиях. Определяются особенности формальнотехнических средств циркового жанра жонглирования, описаны методы их воплощения в сценической репрезентации на цирковом манеже настоящего. Предоставляется краткий анализ исследований по данной проблематике в контексте истории исполнительства. Описывается специфика методических особенностей жонглирования, которая способствует развитию координации, периферийного зрения и контроля предметов, цирковая техника, которую используют как элемент воспитания актерской пластики и сценического движения. Современная цирковая культура в области жонглирования, опираясь на конкретные классические методы и систему, обогащается результатами взаимодействия искусства с новейшими технологиями, материалами, формами. Это дает возможности молодым артистам цирка в области жонглирования получить конкурентоспособность на современных мировых фестивалях и конкурсах.
\end{abstract}


Ключевые слова: цирковое искусство, жонглирование, специфика преподавания, реквизит, тренировки

\title{
Denys I. SHARYKOV, \\ $\mathrm{PhD}$ in Arts,
} Kyiv Municipal Academy of Circus and Performing Arts,

Kyiv, Ukraine, e-mail: d.ballet77@gmail.com, ORCID: 0000-0002-3757-5559

\section{JUGGLING IN MODERN CIRCUS ART: SIGNIFICANCE, FEATURES}

\begin{abstract}
The article describes the specifics of teaching of juggling as a circus genre in nowadays. The peculiarities of the formal and technical means of the circus genre of juggling are determined, the methods of their embodiment in the stage representation at the circus arena of today are described. A brief analysis of research on this issue in the context of the history of performance. The specifics of methodical features of juggling, which promotes the development of coordination, peripheral vision and control of objects, circus technique, which is used as an element of education of acting and stage movement, are described. Modern circus culture in the field of juggling, based on specific classical methods and systems, is enriched by the results of the interaction of art with the latest technologies, materials, forms. It enables young circus artists in the field of juggling to gain competitiveness at modern world festivals and competitions. Juggling is an ancient genre of circus art. Its history begins before our era and continues to our time. The technique of juggling is constantly improved and developed in all possible directions. This is facilitated by both amateurs and professionals of this genre. Each artist brings something new to this genre. The specifics of juggling and representative characteristics indicate that the end result of a local result for a juggler is the creation of a number. Circus number is a
\end{abstract}


work of art of circus art. It is a set in the appropriate structural sequence of elements, which in combination with other stage means of expression reflect the creative task, idea and affect the audience on an emotional level. The current level of development of circus art requires comprehensive training of the artist. The development and staging of a circus number is a long process of searching, compiling, creating and improving, which is the subject of interest of this article. training

Key words: circus art, juggling, specifics of teaching, props,

\section{References}

1. Bardian, F. (2015). Sovetskiy tsirk na pyati kontinentakh [Soviet circus on five continents]. Moscow: Nauka [in Russian].

2. Barinov, V. (2016). Estetika tsirkovogo naiva [Aesthetics of circus naive]. Moscow: Mir [in Russian].

3. Bauman, N. (1962). Iskusstvo zhonglirovaniya [The Art of Juggling]. Moscow: Iskusstvo [in Russian].

4. Gelb, M. Dzh., B'yuzen, T. (2000). Nauchites' uchit'sya ili zhonglirovat' [Learn to learn or to juggle]. Minsk: OOO "Popurri" [in Russian].

5. Gurevich, Z. (1984). O zhanrakh sovetskogo tsirka: uchebnoye posobiye dlya uchilishch tsirkovogo i estradnogo iskusstva i otdeleniy rezhissury tsirka teatr, institutov [On the genres of the Soviet circus: a textbook for schools of circus and variety art and departments of directing the circus theater, institutes]. Moscow: Iskusstvo [in Russian].

6. Dmitriyev, YU. (1963). Sovetskiy tsirk. Ocherki istorii 19171941 [Soviet circus. Essays on the history of 1917-1941]. Moscow: Iskusstvo [in Russian].

7. Kiss, A. (1971). Yesli ty - zhonglor... [If you are a juggler]. Moscow: Iskusstvo [in Russian].

8. Kludskiy, K., Tsibula, V. (1981). Zhizn' na manezhe [Life on the arena]. Moscow: Iskusstvo [in Russian]. 
9. Kuznetsov, Y. (1971). Tsirk: proiskhozhdeniye, razvitiye, perspektivy [Circus: origin, development, prospects]. Moscow: Iskusstvo [in Russian].

10. Makarov, S. (2015). Teatralizatsiya tsirka [Theatricalization of the circu]. Moscow: Librokom [in Russian].

11. Malykhina, M. (2009). Problema vykorystannya syntezu mystetstv u profesiyniy pidhotovtsi artystiv tsyrku [The problem of using the synthesis of arts in the training of circus artists]. Kul'tura $i$ suchasnist', 1, 151-161 [in Ukrainian].

12. Malykhina, M. (2016). Problema stvorennya manezhnogo obrazu [the problem of creating an arena image]. Kul'turnomystets'ki obriyi. Chastyna I. Kyiv, 57-59 [in Ukrainian].

13. Malykhina, M. (2013). Modyfikatsiya tsyrkovoho mystetstva v Ukrayini: 20-i roky XX stolittya [Modification of circus art in Ukraine: the 20 s of the XX century]. Visnyk Natsional'noyi akademiyi kerivnykh kadriv kul'tury i mystetstv, 2, 160-164 [in Ukrainian].

14. Pozhars'ka, O. (2017). Zmist ta funktsiyi tsyrkovoho vydovyshcha [Content and functions of the circus spectacle]. Available at: https://knowledge.allbest.ru/culture/3c0a65625a3a c68a5c43a99521316d27_0.html [in Ukrainian].

15. Romanenkova, YU. (2020). Sovremennoye tsirkovoye iskusstvo kak pole dlya bor'by so stereotipami [Contemporary circus art as a field for combating stereotypes]. Art-platfotma,1, 69-93 [in Russian].

16. Romanenkova, YU. (2020). Suchasna ukrayins'ka tsyrkova shkola yak instrument prezentuvannya krayiny $\mathrm{u}$ svitovomu kul'turnomu prostori [Modern Ukrainian circus school as a tool for presenting the country in the world cultural space]. Molodyi vchenyi, 3(79), 69-73 [in Ukrainian].

17. Romanenkova, YU. (2018). K voprosu o meste tsirkovedeniya $\mathrm{v}$ sovremennoy ukrainskoy gumanitaristike [To the question of the place of circus studies in modern Ukrainian humanities]. Suchasni tendentsiyi rozvytku nauky. Uzhhorod, Kherson, 150-153 [in Russian]. 
18. Romanenkova, YU. (2018). Tsirkovoye iskusstvo kak kul'turnyy marker sovremennoy Ukrainy [Circus art as a cultural marker of modern Ukraine]. Science, research, development. Warszawa, 150-153 [in Russian].

19. Rumyantsev, M. (2015). Na arene sovetskogo tsirka [On the arena of the Soviet circus]. Moscow: Iskusstvo [in Russian].

20. Shiray, A. (1963). Kniga N. E. Baumana "Iskusstvo zhonglirovaniya" [Book by N. E Bauman "The Art of Juggling"]. Sovetskiy tsirk, 7, 34 [in Russian].

21. Shneyer, A., Slavskiy, R. (2016). Tsirk. Malen'kaya entsiklopediya [Circus. Little encycloped]. Moscow: Sovetskaya Entsiklopediya [in Russian].

22. Circopedia. URL: http://www.circopedia.org/Main_Page [in Russian].

23. Romanenkova J., Paliychuk A., Sharykov D., Bratus I., Kuzmenko H., Gunka A. Circus art in modern realities: functions, problems, prospects. Revista inclusiones. 2021. Vol. 8. 571-581 [in English]. 